\title{
Phytoprotection
}

\section{Hymenopterous parasites associated with Phyllonorycter blancardella [Lepidoptera: Gracillariidae] in Nova Scotia and Quebec}

\section{Parasites hyménoptères de la mineuse marbrée, Phyllonorycter blancardella [Lepidoptera : Gracillariidae] en Nouvelle-Écosse et au Québec}

\author{
S.D. Bishop, R.F. Smith, C. Vincent, H. Goulet, J. Huber, G. Gibson, M. Sharkey et \\ J.H. Borden
}

Volume 82, numéro 2, 2001

URI : https://id.erudit.org/iderudit/706217ar

DOI : https://doi.org/10.7202/706217ar

Aller au sommaire du numéro

Éditeur(s)

Société de protection des plantes du Québec (SPPQ)l

ISSN

0031-9511 (imprimé)

1710-1603 (numérique)

Découvrir la revue

Citer cet article

Bishop, S., Smith, R., Vincent, C., Goulet, H., Huber, J., Gibson, G., Sharkey, M. \& Borden, J. (2001). Hymenopterous parasites associated with Phyllonorycter blancardella [Lepidoptera: Gracillariidae] in Nova Scotia and Quebec.

Phytoprotection, 82(2), 65-71. https://doi.org/10.7202/706217ar
Résumé de l'article

Une étude a été effectuée dans des vergers commerciaux et non-traités du Québec et de la Nouvelle-Écosse pour déterminer l'abondance et la diversité des parasites de la mineuse marbrée, Phyllonorycter blancardella [Lepidoptera : Gracillariidae]. Au Québec, 29 espèces de parasites ont été retrouvées et elles appartenaient à 7 familles, soit Aphelinidae, Braconidae, Chalcidae, Eulophidae, Ichneumonidae, Pteromalidae et Scelionidae. Les espèces les plus fréquentes étaient : Pholetesor ornigis (67 \%), Sympiesis marylandensis (11 \%), S. serviceicornis (7\%), Pnigalio maculipes (1,5\%), Tetrasticus spp. (1,2 \%). Toutes les autres espèces représentaient moins de $1 \%$ des espèces trouvées. Pholetesor pedias, une espèce braconide relâchée à Frelighsburg, Québec en 1983 n’a pas été détectée en 1984 et 1985. En Nouvelle-Écosse, 19 espèces ont été trouvées et elles appartenaient à 5 familles, soit Braconidae, Chalcidae, Eulophidae, Ichneumonidae et Pteromalidae. Les espèces les plus fréquentes étaient : Pholetesor ornigis (52 \%), Pnigalio maculipes (14\%), Sympiesis serviceicornis (12\%), S. marylandensis (9,5\%), Sympiesis spp. (5 \%), Horismenus fraternus (1,8 \%), Paraleurocerus sp. (1,3\%), Stictopisthus flaviceps (1,1\%); toutes les autres espèces représentaient moins de $1 \%$ des espèces trouvées. Sept et cinq espèces d'hyperparasites ont été retrouvées en Nouvelle-Écosse et au Québec, respectivement. Sticopisthus bilineatus, S. flaviceps, Euderis sp., Pnigalio epilobii, $P$. pallipes and Paraleurocerus bicoloripes constituent des nouvelles mentions comme parasites de la mineuse marbrée pour l'Amérique du Nord. 


\title{
Hymenopterous parasites associated with Phyllonorycter blancardella [Lepidoptera: Gracillariidae] in Nova Scotia and Quebec
}

\author{
Stephanie D. Bishop ${ }^{1}$, Rob.F. Smith ${ }^{2}$, Charles Vincent ${ }^{3}$, \\ Henri Goulet ${ }^{4}$, John Huber ${ }^{4}$ Gary Gibson ${ }^{4}$, Michael \\ Sharkey ${ }^{5}$, and John H. Borden ${ }^{6}$
}

Received 2001-02-05; accepted 2001-06-13

PHYTOPROTECTION $82: 65-71$

Mined leaves were collected in commercial and unsprayed (no insecticides) apple orchards of Quebec and Nova Scotia to determine the relative abundance and diversity of parasites of the spotted tentiform leafminer, Phyllonorycter blancardella [Lepidoptera: Gracillariidae]. In Quebec, 29 species of leafminer parasites were recovered, belonging to 7 families : Aphelinidae, Braconidae, Chalcidae, Eulophidae, Ichneumonidae, Pteromalidae and Scelionidae. The most prevalent species were Pholetesor ornigis $(67 \%)$, Sympiesis marylandensis $(11 \%)$, S. serviceicornis $(7 \%)$, Pnigalio maculipes (1.5\%), Tetrasticus spp. (1.2\%), while all other species accounted for $<1.0 \%$. Pholetesor pedias, a braconid released in 1983 at Frelighsburg, Quebec, was not found in the 1984 and 1985 surveys. In Nova Scotia, 19 parasite species were recovered, belonging to 5 families : Braconidae, Encyrtidae, Eulophidae, Ichneumonidae and Pteromalidae. The most prevalent species were : Pholetesor ornigis (52\%), Pnigalio maculipes $(14 \%)$, Sympiesis serviceicornis (12\%), S. marylandensis (9.5\%), Sympiesis spp. (5\%), Horismenus fraternus (1.8\%), Paraleurocerus sp. $(1.3 \%)$, Stictopisthus flaviceps (1.1\%), while all other species accounted for $<1 \%$. Seven and five species of hyperparasites were recovered in Nova Scotia and Quebec, respectively. New records for North America for the spotted tentiform leafminer as a host are : Sticopisthus bilineatus, S. flaviceps, Euderis sp., Pnigalio epilobii, P. pallipes and Paraleurocerus bicoloripes.

[Parasites hyménoptères de la mineuse marbrée, Phyllonorycter blancardella [Lepidoptera : Gracillariidae] en Nouvelle-Écosse et au Québec]

1. Agricultural Pest Monitoring, P.O. Box 1086, Wolfville, Nova Scotia, Canada B0P 1X0

2. Atlantic Food and Horticulture Research Centre, Agriculture and Agri-Food Canada, 32 Main St., Kentville, Nova Scotia, Canada B4N 1J5

3. Horticultural Research and Development Centre, Agriculture and Agri-Food Canada, 430 Gouin blvd., Saint-Jean-sur-Richelieu (Quebec), Canada J3B 3E6; corresponding author, e-mail : vincentch@em.agr.ca

4. Eastern Cereals and Oilseed Research Centre, Agriculture and Agri-Food Canada, Ottawa, Ontario, Canada

5. Department of Entomology, University of Kentucky, S-225 Agricultural Science Centre, Lexington, KY, USA 405460091

6. Department of Biological Sciences, Simon Fraser University, Burnaby, British Columbia, Canada V5A 156 
Une étude a été effectuée dans des vergers commerciaux et non-traités du Québec et de la Nouvelle-Écosse pour déterminer l'abondance et la diversité des parasites de la mineuse marbrée, Phyllonorycter blancardella [Lepidoptera : Gracillariidae]. Au Québec, 29 espèces de parasites ont été retrouvées et elles appartenaient à 7 familles, soit Aphelinidae, Braconidae, Chalcidae, Eulophidae, Ichneumonidae, Pteromalidae et Scelionidae. Les espèces les plus fréquentes étaient: Pholetesor ornigis (67\%), Sympiesis marylandensis $(11 \%)$, S. serviceicornis (7 \%), Pnigalio maculipes $(1,5 \%)$, Tetrasticus spp. (1,2\%). Toutes les autres espèces représentaient moins de $1 \%$ des espèces trouvées. Pholetesor pedias, une espèce braconide relâchée à Frelighsburg, Québec en 1983 n'a pas été détectée en 1984 et 1985 . En Nouvelle-Écosse, 19 espèces ont été trouvées et elles appartenaient à 5 familles, soit Braconidae, Chalcidae, Eulophidae, Ichneumonidae et Pteromalidae. Les espèces les plus fréquentes étaient : Pholetesor ornigis (52 \%), Pnigalio maculipes (14\%), Sympiesis serviceicornis (12\%), S. marylandensis (9,5\%), Sympiesis spp. (5\%), Horismenus fraternus $(1,8 \%)$, Paraleurocerus sp. $(1,3 \%)$, Stictopisthus flaviceps $(1,1 \%)$; toutes les autres espèces représentaient moins de $1 \%$ des espèces trouvées. Sept et cinq espèces d'hyperparasites ont été retrouvées en Nouvelle-Écosse et au Québec, respectivement. Sticopisthus bilineatus, S. flaviceps, Euderis sp., Pnigalio epilobii, $P$. pallipes and Paraleurocerus bicoloripes constituent des nouvelles mentions comme parasites de la mineuse marbrée pour l'Amérique du Nord.

\section{INTRODUCTION}

The spotted tentiform leafminer, Phyllonorycter blancardella (F.) [Lepidoptera: Gracillariidae], is an important pest of apple (Malus domestica Borkhausen) in eastern North America (Dutcher and Howitt 1978; Johnson et al. 1976; Maier 1984; Pottinger and LeRoux 1971). Although it occurs in some areas with the apple blotch leafminer, $P$. crataegella (Clemens) (Maier 1983), $P$. blancardella is the dominant species in Ontario, Quebec and Nova Scotia (Bishop 1998; Vincent et al. 1986). In Ontario, populations of $P$. blancardella have developed resistance to organophosphate (Pree et al. 1980) and synthetic pyrethroid insecticides (Pree et al. 1986). Although insecticide resistance in this species has not yet been reported in Quebec or Nova Scotia, alternatives to synthetic insecticides are needed to design sound and sustainable protection programs.

Several surveys of hymenopterous parasitoids of $P$. blancardella have been conducted, and a total of 36 species have been recorded from northeastern
North America (Hagley 1985; Maier 1994; Pottinger and LeRoux 1971; Ridgway and Mahr 1985). The predominant species in each of these studies were the braconid Pholetesor ornigis (Weed) [Hymenoptera : Braconidae] and the eulophid Sympiesis marylandensis (Girault) [Hymenoptera : Eulophidae].

In 1978, the exotic parasitoid Pholetesor pedias (Nixon) [Hymenoptera: Braconidae] was released and established near Guelph, Ontario (Laing and Heraty 1981). Pholetesor pedias individuals obtained from the Biocontrol Laboratory (Guelph University, Ontario) were released on 28 June (12 unsexed individuals) and 20 July (52) 1983 in an untreated (i.e. no insecticides) orchard at the Agriculture Canada Experimental Farm located at Frelighsburg $\left(45^{\circ} 03^{\prime} \mathrm{N}\right.$; $75^{\circ} 50^{\prime}$ W), Quebec. A survey was initiated in 1984 and 1985 to determine its establishment and the relative abundance of the parasitoid fauna of $P$. blancardella.

Little information has been published concerning the parasite fauna of the spotted tentiform leafminer in Nova Scotia. In response to a widespread 
increase in $P$. blancardella population densities in Nova Scotia orchards (R. Smith, unpublished data) and to concerns by apple growers, a survey of the parasitoid fauna was conducted in 1994 and 1995 to identify indigenous natural enemies that could be useful to establish a biocontrol program. Consequently, the surveys were conducted in both untreated (no insecticides) and commercial (treated with pesticides, including insecticides) orchards in Quebec and Nova Scotia.

\section{MATERIALS AND METHODS}

\section{Quebec (1983-1985)}

Collection of parasites were done in June, July and August in two untreated (Frelighsburg and I'Acadie) and three commercial (Saint-Grégoire, Rougemont and Frelighsburg) orchards. Several hundred leaves showing tissuefeeding mines (i.e. containing a fourth or fifth instar larva, pupa or its remains) were collected at random from the canopy of apple trees at a height of approximately $1.5 \mathrm{~m}$. From these collected leaves, 200 mined leaves of each site were selected at random and put per cardboard boxes $(50 \mathrm{~cm} \times 50 \mathrm{~cm} \times 50$ $\mathrm{cm}$ ) that were placed in an insectary. To collect emerging parasites, a bottle was fitted to a transparent plastic funnel installed on top of each box. The bottles were emptied every weekday. In the fall, the leaves were transferred on a tray to search for specimens remaining in the boxes. Collected parasites were mounted and sent to the Agriculture and Agri-Food Canada Eastern Cereals and Oilseed Research Centre in Ottawa for identification. Voucher specimens were deposited in its collection.

\section{Nova Scotia Study (1994-1995)}

Fourteen commercially managed orchards in Kings County, Nova Scotia, were surveyed weekly, from 21 June to 30 November 1994, and 12 April to 30 November 1995 for $P$. blancardella and its associated parasitoids. Fifteen trees were selected as sampling units in each orchard. They were separated by at least two other trees within orchard rows. Six unsprayed wild sites were also monitored weekly. They consisted of two to four trees that had arisen from inadvertent seedlings on unmanaged land.

In both years of the study, two mined leaves were selected from each sample tree weekly, from the last week of June to the last week of November. Leaves were taken to the laboratory and examined under a dissecting microscope. Parasitized leafminer larvae and pupae were placed on moistened filter paper in petri dishes and held in a Conaire ${ }^{\circledR}$ growth cabinet at $20 \pm 1^{\circ} \mathrm{C}, 75 \pm 5 \% \mathrm{RH}$ and 16:8 L:D photoperiod. These were observed weekly until an adult parasitoid emerged or the juvenile stage died. Adult parasitoids were identified by Agriculture and Agri-Food Canada Eastern Cereals and Oilseed Research Centre, Ottawa, Ontario. Voucher specimens of all identified parasitoids were deposited at the Agriculture and Agri-Food Canada Atlantic Food and Horticulture Research Centre, Kentville, Nova Scotia.

The results are reported by management (i.e commercial or unsprayed) of orchards. To evaluate species diversity in each yr-management situations, Simpson's index was calculated (Krebs 1989). Proportions were compared with $G$-tests (Zar 1996) under the null hypothesis of equality of proportions.

\section{RESULTS AND DISCUSSION}

\section{Quebec (1983-1985)}

In Quebec, 29 hymenopterous parasite species (16 genera, seven families) were recovered (Table 1 ), ten of which had been reported by Pottinger and LeRoux (1971). Four species (the eupelmid Eupelmella vesicularis Retzius and the eulophids Zagrammosoma multilineatum multilineatum Ashmead, Sympiesis nigripes Ashmead and Horsimensus fraternus Fitch) mentioned in Pottinger and LeRoux (1971) were not recovered.

Pholetesor ornigis was the most abundant in all samples, ranging from 37 to $63 \%$ in untreated orchards, and 0 to $89 \%$ in commercial orchards using pesticides. Pholetesor ornigis was first reported in Quebec by Parent (1962), and was the predominant species found in southern Quebec by Pottinger and 
LeRoux (1971). The second most abundant species, the eulophid Sympiesis marylandensis, accounted for 12 to $21 \%$ and 2 to $44 \%$ of parasites collected respectively in unsprayed and commercial orchards. Pottinger and LeRoux (1971) report that this species accounts for $70 \%$ of parasitoids in the first leafminer generation and $80 \%$ in the third. The braconid $P$. pedias was not recov- ered in the Quebec survey. Ten percent of the species were found only in commercially managed orchards, compared to $41 \%$ found solely in untreated orchards and $48 \%$ of the species were identified in both sprayed and unsprayed sites. The abundance of parasites was greater in untreated than in commercial orchards (Table 1 ).

Table 1. Relative abundance of $\boldsymbol{P}$. blancardella parasite species in Quebec apple orchards

\begin{tabular}{|c|c|c|c|c|c|c|c|c|}
\hline \multirow[b]{2}{*}{ Family } & \multirow[b]{2}{*}{ Genus and species } & \multicolumn{2}{|c|}{1983} & \multicolumn{2}{|c|}{1984} & \multicolumn{2}{|c|}{1985} & \multirow[b]{2}{*}{ Total } \\
\hline & & $\mathrm{U}^{\mathrm{a}}$ & $C^{a}$ & U & C & U & C & \\
\hline Aphelinidae & Centrodora sp. & $0.0^{\mathrm{b}}$ & 0.0 & 0.0 & 0.4 & 0.0 & 0.0 & 0.1 \\
\hline Braconidae & Pholetesor ornigis (Weed) & 52.1 & 0.0 & 63.4 & 89.3 & 37.3 & 62.1 & 67.3 \\
\hline Chalcidae & Spilochalics sp. & 0.0 & 0.0 & 0.1 & 0.0 & 0.0 & 0.0 & 0.1 \\
\hline Eulophidae & $\begin{array}{l}\text { Chrysocharis laomedon (Walker) }{ }^{c} \\
\text { Chrysocharis polita (Howard) } \\
\text { Chrysocharis sp. } \\
\text { Cirrospilus cictithorax (Girault) } \\
\text { Closterocerus tricinctus (Ashmead) } \text { Closterocerus trifasciatus Westwood }^{c} \\
\text { Pnigalio flavipes (Ashmead) } \\
\text { Pnigalio levis Yoshimoto } \\
\text { Pnigalio maculipes (Crawford) } \\
\text { Pnigalio minio Walker } \\
\text { Pnigalio neolongus Yoshimoto } \\
\text { Pnigalio uroplatae (Howard) } \\
\text { Sympiesis bimaculatipennis (Girault) } \\
\text { Sympiesis dolichogaster Ashmead } \\
\text { Sympiesis marylandensis Girault } \\
\text { Sympiesis sericeicornis (Nees) }{ }^{c} \\
\text { Sympiesis sp. } \\
\text { Tetrasticus sp. } \\
\text { Zagrammosoma nigrolineatum Crawford }\end{array}$ & $\begin{array}{r}0.6 \\
1.2 \\
0.0 \\
0.0 \\
0.0 \\
1.2 \\
0.0 \\
0.0 \\
5.2 \\
0.0 \\
0.0 \\
0.6 \\
0.6 \\
11.6 \\
21.1 \\
4.1 \\
0.0 \\
0.0 \\
0.0\end{array}$ & $\begin{array}{r}33.3 \\
0.0 \\
0.0 \\
0.0 \\
0.0 \\
0.0 \\
0.0 \\
0.0 \\
0.0 \\
0.0 \\
0.0 \\
0.0 \\
11.1 \\
11.1 \\
44.4 \\
0.0 \\
0.0 \\
0.0 \\
0.0\end{array}$ & $\begin{array}{r}0.0 \\
0.0 \\
1.1 \\
0.1 \\
0.0 \\
0.2 \\
0.0 \\
0.2 \\
0.0 \\
0.0 \\
0.1 \\
4.1 \\
0.1 \\
0.0 \\
12.4 \\
11.9 \\
0.2 \\
2.5 \\
1.1\end{array}$ & $\begin{array}{l}0.0 \\
0.0 \\
0.4 \\
0.0 \\
0.0 \\
0.0 \\
1.1 \\
0.4 \\
0.2 \\
0.4 \\
0.0 \\
3.3 \\
0.0 \\
0.0 \\
2.1 \\
0.6 \\
0.2 \\
0.0 \\
0.6\end{array}$ & $\begin{array}{r}0.0 \\
0.0 \\
0.6 \\
0.0 \\
1.1 \\
0.0 \\
0.6 \\
0.0 \\
3.3 \\
0.6 \\
0.0 \\
0.0 \\
0.0 \\
16.0 \\
20.6 \\
12.0 \\
0.0 \\
2.6 \\
2.0\end{array}$ & $\begin{array}{r}1.6 \\
0.0 \\
0.0 \\
0.0 \\
0.0 \\
0.0 \\
4.0 \\
0.0 \\
5.6 \\
2.4 \\
0.0 \\
0.0 \\
0.0 \\
4.8 \\
12.1 \\
6.4 \\
0.0 \\
0.0 \\
0.8\end{array}$ & $\begin{array}{r}0.4 \\
0.1 \\
0.6 \\
0.1 \\
0.1 \\
0.3 \\
0.7 \\
0.3 \\
1.5 \\
0.4 \\
0.1 \\
2.6 \\
0.2 \\
3.4 \\
11.1 \\
6.9 \\
0.2 \\
1.2 \\
0.8\end{array}$ \\
\hline Ichneumonidae & $\begin{array}{l}\text { Scambus (Scambus) decorus Walley } \\
\text { Scambus (Scambus) vesicarius (Ratzeburg) } \\
\text { Stictopisthus bilineatus (Thompson) }{ }^{c}\end{array}$ & $\begin{array}{l}0.0 \\
1.8 \\
0.0\end{array}$ & $\begin{array}{l}0.0 \\
0.0 \\
0.0\end{array}$ & $\begin{array}{l}0.0 \\
0.0 \\
0.0\end{array}$ & $\begin{array}{l}0.2 \\
0.0 \\
0.6\end{array}$ & $\begin{array}{l}0.0 \\
0.0 \\
0.0\end{array}$ & $\begin{array}{l}0.0 \\
0.0 \\
0.0\end{array}$ & $\begin{array}{l}0.1 \\
0.2 \\
0.2\end{array}$ \\
\hline Pteromalidae & $\begin{array}{l}\text { Dibrachys cavus (Walker) } \\
\text { Habrocytus sp. } \\
\text { Hypopteromalus sp. }\end{array}$ & $\begin{array}{l}0.0 \\
0.0 \\
0.0\end{array}$ & $\begin{array}{l}0.0 \\
0.0 \\
0.0\end{array}$ & $\begin{array}{l}0.0 \\
0.7 \\
0.0\end{array}$ & $\begin{array}{l}0.0 \\
0.0 \\
0.0\end{array}$ & $\begin{array}{l}0.6 \\
0.0 \\
2.0\end{array}$ & $\begin{array}{l}0.0 \\
0.0 \\
0.0\end{array}$ & $\begin{array}{l}0.1 \\
0.3 \\
0.3\end{array}$ \\
\hline Scelionidae & Telenomus sp. & 0.0 & 0.0 & 1.2 & 0.0 & 0.0 & 0.0 & 0.5 \\
\hline & $\begin{array}{l}\text { Total no. of parasite specimens collected } \\
\text { Total number of species collected }\end{array}$ & $\begin{array}{r}171 \\
11\end{array}$ & $\begin{array}{l}9 * \\
4\end{array}$ & $\begin{array}{r}571 \\
16\end{array}$ & $\begin{array}{c}481 * \\
14\end{array}$ & $\begin{array}{r}150 \\
13\end{array}$ & $\begin{array}{c}124^{*} \\
9\end{array}$ & $\begin{array}{r}1506 \\
29\end{array}$ \\
\hline $\begin{array}{l}\text { Simpson's } \\
\text { index }\end{array}$ & $\begin{array}{l}\text { Probability of two individuals } \\
\text { being different } \\
\text { No. of equally common species }\end{array}$ & $\begin{array}{l}0.66 \\
2.99\end{array}$ & $\begin{array}{l}0.67 \\
3.00\end{array}$ & $\begin{array}{l}0.57 \\
2.30\end{array}$ & $\begin{array}{l}0.20 \\
1.25\end{array}$ & $\begin{array}{l}0.77 \\
4.45\end{array}$ & $\begin{array}{l}0.59 \\
2.43\end{array}$ & \\
\hline
\end{tabular}

a $U=$ Untreated (no insecticides) apple orchards; $C=$ commercial orchards, treated with insecticides.

b Values in a column represent percent of total number collected by year and orchard management.

c Hyperparasite of braconid and chalcid larvae and pupae.

* The proportion of specimens recovered from unsprayed versus commercial orchard is significantly different at $P=0.05$ (G-tests). 


\section{Nova Scotia (1994-1995)}

In Nova Scotia, 19 species (12 genera, five families) were recovered from the mined leaves (Table 2). The most abundant species recovered in both yr were Pholetesor ornigis ( $52 \%$ of all specimens captured), Pnigalio sp. (P. maculipes or P. flavipes) (14\%), Sympiesis sericeicornis $(12 \%)$ and S. marylandensis $(9 \%)$. Seven (Nova Scotia; Table 2) and five species (Quebec; Table 1) have been reported as hyperparasites that kill larvae and pupae of $P$. ornigis and pupae of chalcidoid species (Maier 1982, 1984, 1994; Pottinger and LeRoux 1971).

In contrast to the Quebec study, 32\% of the species were found only in commercial sprayed orchards, none were found solely in the untreated orchards, while $48 \%$ were found in both sprayed and untreated orchards. Sticopisthus bilineatus $(n=8), S$. flaviceps $(n=29)$, Euderis sp. $(\mathrm{n}=1)$, Pnigalio epilobii ( $\mathrm{n}$ $=1), P$. pallipes $(n=1)$ and Paraleurocerus bicoloripes $(n=1)$ are new records from Phyllonorycter blancardella in North America. Sticopisthus bilineatus and $S$. flaviceps belong to the Mesochorinae, secondary parasites of Braconidae, Ichneumonidae and Tachinidae, and were both collected from $P$. ornigis pupal cases. All other species (Table 2) have been reported from Quebec (Pottinger and LeRoux 1971), Ontario (Hagley 1985; Johnson et al. 1976), Michigan (Dutcher and Howitt 1978), New York (Weires et al. 1980) or

Table 2. Relative abundance of $\boldsymbol{P}$. blancardella parasite species in Nova Scotia apple orchards

\begin{tabular}{|c|c|c|c|c|c|c|}
\hline \multirow[b]{2}{*}{ Family } & \multirow[b]{2}{*}{ Genus and species } & \multicolumn{2}{|c|}{1994} & \multicolumn{2}{|c|}{1995} & \multirow[b]{2}{*}{ Total } \\
\hline & & $U^{a}$ & $\mathrm{C}^{\mathrm{a}}$ & $\mathrm{U}^{\mathrm{a}}$ & $\mathrm{C}^{\mathrm{a}}$ & \\
\hline \multirow{2}{*}{$\begin{array}{l}\text { Braconidae } \\
\text { Encyrtidae }\end{array}$} & Pholetesor ornigis (Weed) & $46.6^{\mathbf{b}}$ & 47.6 & 42.6 & 56.4 & 51.8 \\
\hline & $\begin{array}{l}\text { Paraleurocerus sp. } \\
\text { (? bicoloripes (Girault)) }\end{array}$ & 0.0 & 0.7 & 8.3 & 0.4 & 1.3 \\
\hline \multirow[t]{13}{*}{ Eulophidae } & Chrysocharis laomedon (Walker) ${ }^{c}$ & 4.0 & 0.7 & 1.2 & 0.2 & 0.2 \\
\hline & Cirrospilus sp.1 & 0.6 & 0.1 & 3.5 & 0.4 & 0.2 \\
\hline & Cirrospilus sp.2 & 0.0 & 0.2 & 0.0 & 0.3 & 0.6 \\
\hline & Closterocerus trifasciatus Westwood & 0.0 & 0.0 & 0.0 & 0.2 & 0.1 \\
\hline & Euderis sp. & 0.0 & 0.0 & 0.0 & 0.1 & 0.1 \\
\hline & $\begin{array}{l}\text { Horismenus fraternus (Fitch) }{ }^{c} \\
\text { Pnigalio flavipes (Ashmead) or }\end{array}$ & 6.0 & 1.1 & 0.7 & 1.9 & 1.8 \\
\hline & P. maculipes (Crawford) & 7.3 & 12.2 & 7.5 & 17.5 & 14.3 \\
\hline & Pnigalio ?levis Yoshimoto or P. epilobii Boucek & 0.0 & 0.0 & 0.0 & 0.1 & 0.1 \\
\hline & Pnigalio pallipes (Provancher) & 0.0 & 0.0 & 0.0 & 0.1 & 0.1 \\
\hline & Sympiesis bimaculatipennis (Girault) ${ }^{c}$ & 0.0 & 0.3 & 0.0 & 0.1 & 0.2 \\
\hline & Sympiesis marylandensis Girault & 17.3 & 21.4 & 1.9 & 2.7 & 9.5 \\
\hline & Sympiesis sericeicornis (Nees) ${ }^{c}$ & 4.0 & 7.2 & 21.9 & 13.8 & 12.1 \\
\hline & Sympiesis sp. & 6.0 & 5.1 & 7.6 & 4.6 & 5.3 \\
\hline \multirow[t]{3}{*}{ Ichneumonidae } & Scambus (Scambus) sp. & 2.0 & 1.6 & 1.2 & 0.4 & 0.9 \\
\hline & Stictopisthus bilineatus (Thompson) ${ }^{\mathrm{C}}$ & 1.3 & 0.3 & 0.7 & 0.1 & 0.3 \\
\hline & Stictopisthus flaviceps (Provancher) ${ }^{\mathrm{c}}$ & 5.0 & 0.9 & 2.3 & 0.5 & 1.1 \\
\hline \multirow[t]{2}{*}{ Pteromalidae } & Unknown & 0.0 & 0.0 & 0.0 & 0.1 & 0.1 \\
\hline & $\begin{array}{l}\text { Total no. of parasite specimens collected } \\
\text { Total number of species collected }\end{array}$ & $\begin{array}{c}150^{*} \\
11\end{array}$ & $\begin{array}{r}831 \\
14\end{array}$ & $\begin{array}{c}251^{*} \\
12\end{array}$ & $\begin{array}{r}1408 \\
19\end{array}$ & $\begin{array}{r}2640 \\
19\end{array}$ \\
\hline $\begin{array}{l}\text { Simpson's } \\
\text { index }\end{array}$ & $\begin{array}{l}\text { Probability of two individuals being different } \\
\text { No. of equally common species }\end{array}$ & $\begin{array}{l}0.73 \\
3.76\end{array}$ & $\begin{array}{l}0.70 \\
3.38\end{array}$ & $\begin{array}{l}0.75 \\
3.99\end{array}$ & $\begin{array}{l}0.63 \\
2.69\end{array}$ & \\
\hline
\end{tabular}

a $U=$ Untreated (no insecticides) apple orchards; $C=$ commercial orchards, treated with insecticides, under an IPM program.

b Values in a column represent percent of total number collected by year and orchard management.

c Hyperparasite of braconid and chalcid larvae and pupae.

* The proportion of specimens recovered from unsprayed versus commercial orchard is significantly different at $P=0.05$ ( $G$-tests). 
Connecticut (Maier 1984, 1994). For both $\mathrm{yr}$ in the Nova Scotia study, the abundance of specimens was greatest in the commercial orchards that operated under an Integrated Pest Management system that minimizes use of the harsher, more disruptive pesticides. We suggest that this, coupled with annual consistent leafminer populations, has nurtured and sustained abundant parasite numbers.

In conclusion, in both provinces and in both commercial or unsprayed orchards, the braconid Pholetesor ornigis was the most $(>37 \%$ ) prevalent of parasite species, except in commercial orchards of Quebec in 1983. The parasite fauna of Quebec was more diverse, as more families and species were found in Quebec ( 7 families, 29 species) than in Nova Scotia (5 families, 19 species). Simpson's index suggests that the species collected were evenly distributed among the samples for both untreated and commercial orchards. Finally, six species are new records for North America as parasites of the spotted tentiform leafminer.

\section{ACKNOWLEDGMENTS}

We thank Michael Hardman, Ken Macrae, Susan Rigby, Cory Sheffield and Gordon Leslie, Agriculture and Agrifood Canada, Atlantic Food and Horticulture Research Centre, Kentville, Nova Scotia; Léo-Guy Simard and Benoit Rancourt, Agriculture and Agri-Food Canada, Horticultural Research and Development Center, Saint-Jean-surRichelieu, Quebec; Erika Bent, Alana Eaton and Beth Bishop, Agricultural Pest Monitoring, Wolfville, Nova Scotia. The support of the Nova Scotia Fruit Grower's Association and its members is acknowledged, as is funding through operational grants from Pest Management Alternatives Office to Agricultural Pest Monitoring and from Agriculture and Agri-Food Canada Matching Investment Initiatives to R.F. Smith. This is contribution no 2235 of the Atlantic Food and Horticulture Research Centre and contribution no. 335/2001.07.01R of the Horticultural Research and Development Center.

\section{REFERENCES}

Bishop, S.D. 1998. Seasonal occurrence of the spotted tentiform leafminer, Phyllonorycter blancardella (F.), and its parasitoids in Nova Scotia. Master of Pest Management thesis, Simon Fraser University, Burnaby, British Columbia. $50 \mathrm{pp}$.

Dutcher, J.D., and A.J. Howitt. 1978. Bionomics and control of Lithocolletis blancardella in Michigan. J. Econ. Entomol. $71: 736-738$.

Hagley, E.C.A. 1985. Parasites recovered from the overwintering generation of the spotted tentiform leafminer, Phyllonorycter blancardella (Lepidoptera: Gracillariidae) in pest management orchards in southern Ontario. Can. Entomol. $117: 371-374$.

Johnson, E.F., J.E. Laing, and R. Trottier. 1976. The seasonal occurrence of Lithocolletis blancardella (Gracillariidae), and its major natural enemies in Ontario apple orchards. Proc. Entomol. Soc. Ontario $107: 31-45$.

Krebs, C.J. 1989. Ecological methodology. Harper Collins Publishers, New York. 654 pp.

Laing, J.E., and J.M. Heraty. 1981. Establishment in Canada of the parasite Apanteles pedias Nixon on the spotted tentiform leafminer, Phyllonorycter blancardella (Fabr.). Environ. Entomol. 10 : 933-935.

Maier, C.T. 1982. Parasitism of the apple blotch leafminer, Phyllonorycter crataegella (Lepidoptera : Gracillariidae), on sprayed and unsprayed apple trees in Connecticut. Environ. Entomol. 11 : 603-610.

Maier, C.T. 1983. Relative abundance of the spotted tentiform leafminer, Phyllonorycter blancardella (F.), and the apple blotch leafminer, $P$. crataegella (Clements) (Lepidoptera : Gracillariidae), on sprayed and unsprayed apple trees in Connecticut. Ann. Entomol. Soc. Am. 76 : 992-995.

Maier, C.T. 1984. Abundance and phenology of parasitoids of the spotted tentiform leafminer, Phyllonorycter blancardella (Lepidoptera : Gracillariidae), in Connecticut. Can. Entomol. 116 : 443-449.

Maier, C.T. 1994. Biology and impact of parasitoids of Phyllonorycter blancardella and $P$. crataegella (Lepidoptera : Gracillariidae), in North American apple orchards. Pages 6-24 in C.T. Maier (ed.), Integrated management of tentiform leafminers, Phyllonorycterspp. (Lepidoptera : Gracillariidae), in North American apple orchards. Thomas Say Publications in Entomology. Entomological Society of America, Lanham, MD. 
Parent, B. 1962. Observations sur trois nouveaux insectes nuisibles aux pommiers dans le Québec: Thammnosphecia scitula scitula Harris (Lépidoptères : Aegeriidae), Lithocolletis craetagella Clem. (Lépidoptères : Lithocolletidae), et Quadraspidiotus ostreaeformis Curtis (Homoptères : Diaspididae). Ann. Soc. Entomol. Qué. 7 : 19-24.

Pottinger, R.P., and E.J. LeRoux. 1971. The biology and dynamics of Lithocolletis blancardella (Lepidoptera : Gracillariidae). Mem. Entomol. Soc. Can. 77.

Pree, D.J., E.A.C. Hagley, C.M. Simpson, and A. Hikichi. 1980. Resistance of the spotted tentiform leafminer, Phyllonorycter blancardella to organophosphorous insecticides in southern Ontario. Can. Entomol. 112 : 469-474.

Pree, D., J.D.B. Marshall, and D.E. Archibald. 1986. Resistance to pyrethroid insecticides in the spotted tentiform leafminer, Phyllonorycter blancardella in southern Ontario. J. Econ. Entomol. 79 : 318-322.
Ridgway, N.M., and D.L. Mahr. 1985. Natural enemies of the spotted tentiform leafminer, Phyllonorycter blancardella (Lepidoptera : Gracillariidae), in sprayed and unsprayed apple orchards in Wisconsin. Environ. Entomol. 14 : 459-463.

Vincent, C., M. Mailloux, and E.A.C. Hagley. 1986. Nonsticky pheromone-baited traps for monitoring the spotted tentiform leafminer (Lepidoptera : Gracilliariidae). J. Econ. Entomol. 79 : 1666-1670.

Weires, R.W., D.R. Davis, J.R. Leeper, and W.H. Reissig. 1980. Distribution and parasitism of gracillariid leafminers on apple in the Northeast. Ann. Entomol. Soc. Am. $73: 541-546$.

Zar, J H. 1996. Biostatistical analysis. 3rd ed. Prentice Hall, Upper Saddle River, New Jersey. 662 pp. 